\title{
The Managers of Social Engineering
}

\begin{abstract}
This chapter discusses the implementation of scientific management theories in the context of the Guided Democracy's revolutionary effort to remake the Indonesian person. Studies into the administrative problems in the early 1950s has pointed out the cultural problem of administration. Classes on such themes as leadership strengthened the idea of a cultural pathology rooted in feudal Indonesian culture. Instead, an idealized image of the village with its corporatist values of gotong royong became one of the mainstay in the discussion of Indonesian administration. This would translate in the creation of a series of institution meant to discipline the civil service and wider population. Indoctrination courses, surveillance and retooling were the means to which the behavioral problem of the Indonesian man could be rationalized so as to support development. The support for this behavioral indoctrination came from both scientific management and Indonesian ideas of traditional corporatism. The concept of discipline was bifurcated within the divide between the experts and the rest. Thus, Indonesian behavioral discipline was often a form of re-traditionalization allowing for the expert to take on the authority of tradition. This again highlights the ease with which scientific management was reincarnated to support an Indonesian corporative order that was illiberal and undemocratic.
\end{abstract}

\section{Keywords}

cultural pathology - traditional corporatism - managerial indoctrination re-traditionalization

This chapter discusses both the implementation of scientific management and the efforts of the government to instil discipline in its civil service with the stated aim of eradicating corruption. The policymakers at the national level assumed that the problem of corruption was the Indonesian Man himself because he was, in their eyes, incapable, inefficient, and corrupt. Thus, the best way to deal with this was through guided corporatism, which required the restructuring of society within the lines of state authority. To allow greater freedom at the local, decentralized level would be to acknowledge the relevance 
of liberalism. Instead, efforts were made to discipline the bureaucracy through restricting the authority of the regions by implementing the BappenasBakopda-Baperdep planning structure. The focus on control and discipline inevitably involved the military. The expansion of the bureaucratic and business managerial class enabled the military to join the elite.

'Leadership' capabilities, the spatial structure of offices and homes, and the very behaviour of managers were to be designed through time-motion studies and other scientifically managed planning tools. The management would, in turn, impose discipline on the lower levels of productive society. The Training Within Industry (TWI) programme would teach mid-level managers how to control the labour force. ${ }^{1}$ Typical of twentieth-century ideas on the state, the Guided Democracy policymakers believed that they could control and discipline Indonesian society through state institutions. Even as this discipline was applied in the 196os, doubt existed about the success of the exercise. The Guided Democracy state professed that Indonesian society, history, and culture would form the foundation of a new society. Instead, culture was manipulated; people were disciplined by social engineering in an effort to push through a state-centred modernization project. Social science was used both as a mechanism for that process and to provide the tools to enforce changes.

\section{The Cultural Pathology of the Indonesian Manager}

National planning would supposedly dispense with the problem of weak government coordination. Yet, that only represented half of the issue. The other half had to address how to efficiently and effectively reform the civil service. The 195os' bureaucracy was largely assumed to be bifurcated, with a small but effective centre where the experts congregated, and a large and inefficient, but politically active, periphery. The creation of an efficient periphery was a daunting task, but the aim was to at least expand expertise into a larger portion of the government. Yet, management was not confined to the creation of effective bureaucrats but also embraced the training of effective managers for both state-owned and private companies. The implementation of modern scientific management must be seen as occurring alongside the implementation of the ideals of Guided Democracy. Like the failed corporatist national-planning project of the Depernas, the introduction of scientific management came from the idea of creating a new and modern Indonesian person. The roots of

1 ANRI, Mohammad Bondan, inv. nos. 692, 734, 735, and 736 . 
these efforts were firmly planted in the disappointing failure of the Indonesian character during the previous laissez-faire period. This was largely related to the 'crisis of leadership' and culture that had pervaded the parliamentarydemocracy period. ${ }^{2}$ Writing in 1955 , Soedjatmoko said of the Indonesian inability for development:

The crisis in which we find ourselves is clearly a crisis of leadership [...] Herein lies the failure of the old leadership which has guided us to the gateway of independence but is unable to disengage from the viewpoint which brought the first phase to a successful end and cannot adjust itself to the demands of the second. ${ }^{3}$

Soedjatmoko titled his article in De Nieuwe Stem 'The crisis in the Indonesian culture'. The profound doubt in the capability of the Indonesian to modernize was long-standing amongst the colonialists. The idea of a plural society was predicated on a perspective that saw a deep chasm between traditional Indonesian society and modern Western society. This can be seen, for instance, in Boeke's theory of dualism, which stressed that Indonesian traditional cultural characteristics were not compatible with the rational maximization drive of the West. ${ }^{4}$ This idea was strengthened in the 1950s, when Indonesian labour productivity was said to be among the lowest in the world. ${ }^{5}$

The Guided Democracy's policy towards this cultural impediment was to home in on what it considered the underlying problem: the authority of the civil service. The inability of Indonesian managers to give orders to subordinates was a puzzling aspect that had been noted by many Western experts. Donald Fagg contended that the Javanese notion of authority required the creation of a useful fiction of unanimous support. That the manager's authority was weak and the clique structure limited his ability to implement action

2 Closely related to this is the effect of the doctrine of 'revolutionary nationalism' and of Indonesia's pre-colonial culture on the economy. See Justus M. van der Kroef, 'Economic Development in Indonesia: Some Social and Cultural Impediments', Economic Development and Cultural Change, 4/2 (January 1956), 116-33.

3 Soedjatmoko, 'De crisis in de Indonesische cultuur', De Nieuwe Stem, 10 (1955), 328-9.

4 Boeke, Economics and Economic Policy, 10-20 and 209-29. Boeke stressed the differences between the pre-capitalist village economy and the industrial capitalism of the West. He stressed the need to tailor different policies for different economic and population sectors (the dual societies), a position that was anathema to the nationalist notion of the ability of the Indonesian to become modern.

5 Edgar McVoy, 'Some Aspects of Labor and Economic Development in Indonesia', Ekonomi dan Keuangan Indonesia, 7 (1954), 804. 
was beside the point. ${ }^{6}$ That a superior's command could, without much consequence, be disobeyed was an important indication of the crisis of authority, even more so when the superior himself for various reasons was hesitant to use his authority. Theories on the failure of vertical authority in the period mostly link it to the failure of Javanese culture. ${ }^{7}$

The Guided Democracy was revolutionary in character precisely because of its emphasis on recreating the individual. In a mass meeting in Medan in 1962, Sukarno stated: 'Our revolution is a cultural revolution, a historical revolution, a national revolution, a military revolution, yes a revolution "to create a new Indonesian man".' ${ }^{\text {W }}$ hat was significant was the extent to which Guided Democracy as an ideology and scientific management coincided in their views on cultural and behavioural change. Garth N. Jones, one of the experts sent to work with the LAN in the early 196os, thought that 'innovations and modifications, in a system of public administration, are usually possible only if large numbers of people, inside and outside of government circles, change and adapt important aspects of their whole cultural complex of believing, behaving, acting and doing. Significant development and improvements generally occur only with cultural changes. ${ }^{9}$ Leon Mears termed the process 'remanagement' to emphasize the 'revolutionary' character of the process that was to build a radically different management structure compared to the one before. $^{10}$

Although practically all expertise in the field of management came from American universities, there was a decided, state-control bias towards the studies and recommendations made for both planning and management. The market and 'competition' stayed out of the equation. Post-war views on the role of the state were an important component. This modernist perspective placed trust in the efficacy of the social sciences and this perspective

6 Donald Fagg, 'Authority and Social Structure. A Study of Javanese Bureaucracy', PhD dissertation, Harvard University, Cambridge, 1959, 565-8.

7 Harry Benda insisted that the roots of Indonesian corruption came from pre-colonial Java; see Harry Benda, 'Decolonization in Indonesia: The Problem of Continuity and Change', The American Historical Review, 70/4 (July 1965), 1058-73. This may also partly have been a result of the fact that many of the most distinguished 'Indologists' of the period - Benedict Anderson, Clifford Geertz, et cetera - were anthropologists and thus there was a tendency to look to the cultural roots of the Indonesian problem.

8 R. M. Soeparto, 'Djiwa Pahlawan', Bulletin Lembaga Administrasi Negara, 9 (1962).

9 Garth N. Jones, 'Some Critical Areas concerning Assistance in Public Administration for Indonesia', Bulletin Lembaga Administrasi Negara, 1 (1961), 3.

10 Mohammad Sadli, 'Masalah Perusahaan Negara di Indonesia. Laporan Symposium pada Latihan Pembangunan Ketatalaksanaan', in Madjallah Perusahaan Negara, 2/18 (June 1962), 7 . 


\section{Penjakit "Babi Kudja”....}

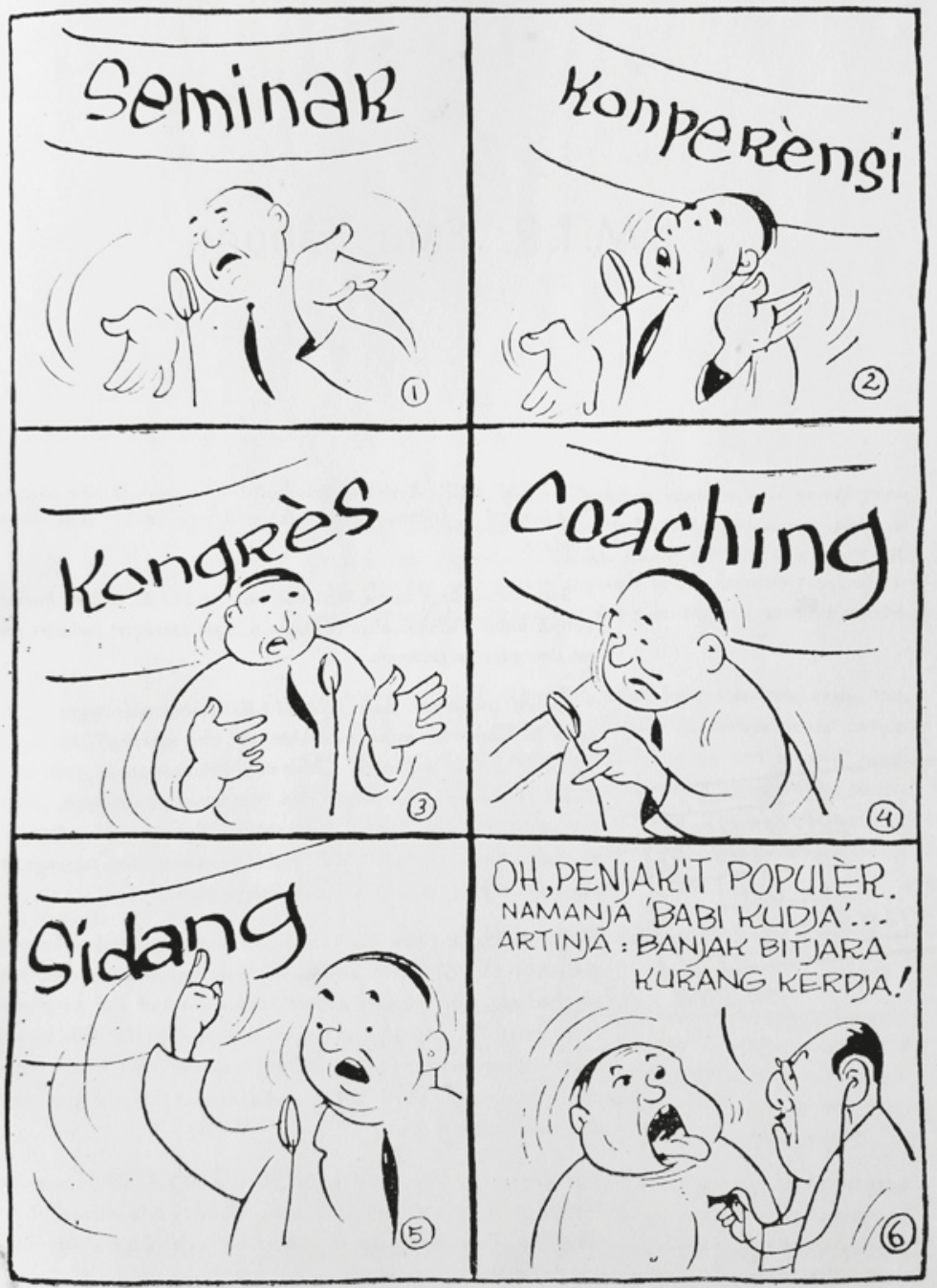

FIGURE 7 A self-critical cartoon on the culture of Indonesian manager published at a government magazine

SOURCE: MADJALAH INDUSTRI RAKJAT, NO. 1 (II) JANUARY 1963, P. 3 
was shared by both the capitalist and communist worlds. Thus, the fact that American social scientists conducted much of the research did not reduce the extent of the state's top-down and expert-based control. By the 196os, the experiences of technical assistance had become a subject of study in their own right. The 'tools of cooperation' were already well institutionalized, allowing for the transfer of knowledge. These 'tools' included general surveys, advisory missions, operating missions, service offices, university contracts, private contracts, visiting professors, seminars, conferences and workshops, training centres, and scholarships for studying and training abroad. ${ }^{11}$ Even so, there were calls for the creation of a specifically Indonesian form of management. As Assegaff phrased it: 'It is apparent that our management experts should start researching, unearthing, and looking for a management style that is in line with our Indonesian socialism. ${ }^{12}$

\section{Rationalizing the Manager's Leadership Position}

By the late 1950s and early 196os, American-trained Indonesian social scientists had begun to study Indonesian culture and to analyse the Indonesian's potential as a modern person and a good manager. Anthropologists, sociologists, and political scientists started to study Indonesia's political and social culture in order to understand the weaknesses of the Indonesian man. Koentjaraningrat studied the village concept of gotong rojong in the early 196 os. $^{13}$ The sociologist Selo Soemardjan studied the changes and development of the civil service in the feudal heartland of Yogyakarta. ${ }^{14}$

Soegito Reksodihardjo, a disciple of management expert Harold Koontz, appraised Indonesia's managerial development by posing the question 'Is the Indonesian fit to become a manager?' He answered in the affirmative, but in order to clinch his argument he had to deal with Boeke's theory of economic dualism. According to Soegito, Boeke's 'dissertation was an attack on the traditional method of dealing with the economic problems of Indonesia, which was still based on the deductive approach and very much influenced by the

11 Philip M. Glick, The Administration of Technical Assistance: Growth in the Americas (Chicago: the University of Chicago Press, 1957), 99-10o.

12 Assegaff, 'Aspek Management dalam Pembangunan Semesta Berentjana', 275.

13 Koentjaraningrat, Some Social-Anthropological Observations of Gotongrojong in Two Villages of Central Java (Ithaca: Cornell University Press, 1961).

14 Selo Soemardjan, Social Changes in Jogjakarta (Ithaca: Cornell University Press, 1962). 
juridical background of the economic curricula in the universities of that period. ${ }^{15}$ Boeke linked cultural values to economic growth. The Indonesian did not make this link because his social environment produced cultural values with social, not economic, motives. Soegito criticized Boeke's understanding of the economic motive and argued that Indonesian farmers made decisions based on sound, rational principles. This rationality depended on how far the person had climbed up the ladder of modernity:

With the increase in the general level of education it is to be expected that rationality will gain in importance among the broader stratum of 'the common people'. When such is the case, it will also be less difficult to make them aware of the importance of such terms as 'effectiveness' and 'efficiency', and a 'rational' or 'business-like' attitude can be eventually mastered. As long as the average educational levels are very low, emotional, traditional and/or social views are more dominant, and although not impossible, it nevertheless will require considerably more effort to implement a rational or systematic idea. ${ }^{16}$

By portraying this image of the irrational Indonesian masses as being on a lower rung of the ladder, Reksodihardjo positioned the managerial class securely as the rational leaders. He continued:

If the economy were left to the masses, the result would probably be that either the subsistence level would persist or that the economy would collapse quickly. First of all, the very low level of education does not permit the people to know much about other needs beside those which are very basic, and with which they are already familiar by tradition. Second, even if they are fully aware of their wants, it is still a question whether or not they can do much to alleviate the shortcomings, since the general low level of income does not allow any significant capital accumulation. Third, even the small proportion of the middle class cannot be entrusted with the task of becoming agents for progress. ${ }^{17}$

15 Soegito Reksodihardjo, 'Skills Investment in a Developing Country: An Appraisal of Management Development for Indonesia', PhD dissertation, University of California, Los Angeles, 1963, 170 .

16 Reksodihardjo, 'Skills Investment in a Developing Country', 154-5.

17 Reksodihardjo, 'Skills Investment in a Developing Country', 216. 
This tension between modernity and tradition was even more explicitly expressed in discussions on the 'traditional value' of gotong rojong or communal cooperation. M. Widojoko Notoatmodjo's dissertation, titled 'Gotong Rojong in Indonesian Administration, a Concept of Human Relations', defended at Indiana University in 1962, sought to understand how the traditional value of gotong rojong could be applied to solve Indonesia's managerial woes. Notoatmodjo's discussed three case studies in order to analyse the situations in which gotong rojong was used effectively. He found several factors which determined the effectiveness of gotong rojong: environmental background, that is, whether someone was from a rural, semi-urban, or urban background; togetherness, that is, the communality of the person's environment, cultural background, education, profession, or social status; their understanding of gotong rojong; the degree of practice of gotong rojong; the degree of rationality, that is, whether a person is more inclined to be emotional or rational or both; and the tendency for collectivism. ${ }^{18}$

Like Reksodihardjo's analysis, Notoatmodjo focused mainly on the division between traditional and modern cultural traits. He explained that gotong rojong 'as a social institution has been known and practiced throughout Indonesia for more than four thousand years, from the time of the population immigration from the mainland of Asia about 2000 BC. ${ }^{19}$ However, its application in the modern period was effective only if the individual had not yet been Westernized. Notoatmodjo continued: 'The domain of gotong rojong is any original and untouched village community in Indonesia, the kind of village community in which traditional adat law is a guiding principle for every member of the community, and where Western influence has not yet been felt in the way of life of the members of that community.' ${ }^{20}$ He believed that gotong rojong could only work among those who had not been tainted by the competitive spirit of Westerners, whose individualist tendencies would lead to the disintegration of its efficacy. Notoatmodjo saw the application of gotong rojong as a compromise to modernity. Instead of implementing full Westernization, the elites of Indonesia wanted to maintain a modernized Indonesian culture. Thus, the modern idea of gotong rojong was, according to Notoatmodjo, a new creation of Indonesian intellectuals who had enjoyed Western education and training. ${ }^{21}$

18 M. W. Notoatmodjo, 'Gotong Rojong in Indonesian Administration, a Concept of Human Relations', PhD dissertation, Indiana University, Bloomington, 1962, 196.

19 Notoatmodjo, 'Gotong Rojong in Indonesian Administration', 205.

20 Notoatmodjo, 'Gotong Rojong in Indonesian Administration', 205-6.

21 Notoatmodjo, 'Gotong Rojong in Indonesian Administration', 218. 
The modern reinterpretation of gotong rojong was shaped through the reinterpretation of ancient values..$^{22}$ Instead of individualism and competition, the new Indonesian man was to work within a highly corporatist social system. This was at least imagined to be the case. Yet, the push for the incorporation of 'traditional values' strengthened the idea of the dangers of the masses; they were not yet ready and thus had to be led by those who were both rational and ready. These rational persons were the managers. In other words, a tension existed between the assumptions made about the pathological nature of the Indonesian character and the efficacy of the new Indonesian managers. There was thus a ready acceptance of values, both modern and traditional, which would help the managerial class to achieve control, despite the fact that such values kept the Indonesian man in a traditional position.

This bifurcated image of the managers as both rational agents and suffering from a damaged culture is important in understanding how the managerial ideology developed in Indonesia. It is not merely interested in efficiency, it may not even be its main goal. The goal was to imbue the new elite class with a modicum of legitimacy as rational, modernizing agents amidst a sea of irrational, but soon to be rational Indonesian peasants. Elite production, as we have seen, was institutionalized through education. How were managers produced?

\section{Business Management}

Management Week (Pekan Management), which took place in 1959, was the first government-sponsored, short-term managerial course. In January 1959, in response to the November 1958 Lynton and Caldwell report, the BPN called a meeting attended by several ministries, the LAN, and the FEUI. The meeting created a working committee whose members included Dr Subroto, Dr Sadli, and Drs. ${ }^{23}$ Panglaykim and Arifin Abdurachman from the LAN, and Achmad Ali from the BPN. After consulting the BAPPIT and the Trading Companies Management Board (Badan Urusan Dagang, BUD), it was agreed to organize the Management Week. It was also decided that top company managers were to be

22 In fact, research has pointed to its creation as recent. Javanese farmers themselves first heard the term around the mid 195os. John R. Bowen, 'On the Political Construction of Tradition: Gotong Royong in Indonesia', The Journal of Asian Studies, 45/3 (May 1986), $545^{-61 .}$

23 Drs. is short for doctorandus (Dutch) or doktorandus (Indonesian); it is a title formerly used for doctoral candidates in the Netherlands and Indonesia.' 
sent to study on advanced management programmes such as the one in Baguio in the Philippines. ${ }^{24}$ On 20 February 1959, the committee concluded that the development of managerial manpower should be divided into three levels: a long-term one that involved five years of academic training, a medium-term one involving two to three years of semi-academic training, and a short-term one of two to three years' company management training. ${ }^{25}$

As a continuation of the Management Week, the FEUI created a Course on Development Management (Latihan Pembangunan Ketatalaksanaan, LPK) in cooperation with the Ford Foundation and the University of California. The programme was initially devised by alumni of the Advanced Management Programme Baguio, a Harvard-led programme that provided business management training for Asian managers. With Ford Foundation money, the alumni approached the FEUI to start a local programme. ${ }^{26}$ The programme focused first on collecting business case methods and business cases, and Dr Rossal J. Johnson from Northwestern University and Dale L. McKeen from San Francisco State College were sent to Indonesia develop the programme for two years. ${ }^{27}$ The programme accepted high-level managers proposed by their company or office, who would work and live together for a period of six weeks at a hotel in the highlands of Puncak near Jakarta. The first class on the LPK had fifty-eight students: thirteen from state-owned companies, thirtyfive from private companies, and ten army officers. They discussed fourteen Indonesian business cases along with fifty-three foreign business cases. There were fifteen teachers, two professors from Gadjah Mada University and the rest from the, most of them American professors who were teaching on a Ford Foundation-University of California programme. Nine assistants were lent by UC to the LPK to help the students with their studies. Each participant was given ten books covering topics from accounting to personnel management. The programme had a small library containing eighty-seven books, many of them used for reading assignments. The classes were usually divided into two groups, which changed every two weeks. ${ }^{28}$

Business management courses had been on offer in Indonesia at the FEUI since the early 195 os and followed the Dutch pattern. To begin with, the faculty

24 Ali Budiardjo, 'Sambutan Mr. Ali Budiardjo berkenaan dengan Pekan Management,' Madjalah Ekonomi, 1/2-3 (June/September 1959), 163-4.

25 Budiardjo, 'Sambutan Mr. Ali Budiardjo', 164.

26 Panglaykim, Report on Business Management Training in Indonesia (Jakarta: n.n., 1959), $10-12$.

27 Barli Halim, 'Latihan Pembangunan Ketatalaksanaan I', Fortuna, 2/14 (May 1961), 85-9.

28 Barli Halim, 'Latihan Pembangunan Ketatalaksanaan II', Fortuna, 2/15 (June 1961), 162-6. 
members were mostly Dutch professors. With the deteriorating relationship with the Netherlands, their numbers had tapered off by 1954. This was compensated for by an agreement between the University of California, the Ford Foundation, and the University of Indonesia to provide teachers and send faculty members to complete their educations at Berkeley and other places in the United States. Until 1963, around twenty American professors were assisting with teaching at the FEUI, while fifty to sixty Indonesians were being trained at various American universities. A similar arrangement was in place between Gadjah Mada University (Universitas Gadjah Mada, UGM) and the University of Wisconsin, whereby the former sent faculty members to Madison for education. The UGM also established research cooperation with Yale University. Outside the United States, the Colombo Plan provided opportunities for education in Australia, Great Britain, and other countries. ${ }^{29}$

The гтв in Bandung created a business management training course in cooperation with the West Java Council of Trade and Companies (Dewan Perdagangan dan Perusahaan Djawa Barat) and, later on, with the Bamunas of West Java. By 1962, there were four classes with a total of 323 students. ${ }^{30}$ Between 1959 and 1965 , at least six hundred businessmen took the two-year course. ${ }^{31}$

The Ministry of Development (Kementerian Pembangunan) held a Seminar on Industrial Management and Business Administration, dubbed 'sıм BA', in the late 1950s which focused on industrial management. sImBA cooperated with the Bappit. ${ }^{32}$ The courses arranged by the government sometimes involved cooperation from the universities and constituted a major effort by the 1950s' state to increase efficiency, as exemplified by the TwI programme and its Guided Democracy incarnation, the Productivity Institute (Lembaga Produktiviteit). In addition to courses, the Productivity Institute also arranged productivity seminars for the Academy of Company Heads (Akademi Pimpinan Perusahaan) ${ }^{33}$ and other state institutes, such as the Rail Office (Djawatan Kereta Api), which covered engineering methods and work-study courses. The Productivity Institute also provided a six-week training programme for master

29 Herman Johannes, Laporan Tahunan Universitas Gadjah Mada Tahun Pengadjaran 1962/ 1963 (Yogyakarta: UGM, 1963), 5, 15-17.

$30 \quad$ 'Pendidikan Manager di Indonesia', Fortuna, $3 / 26$ (May 1962), 81-3.

31 Sedjarah Perkembangan Pembangunan Daerah Djawa Barat Tahun 1946-1965 (Bandung: Bakopda Djawa Barat, 1965), 232.

32 'Pendidikan Manager di Indonesia', 83.

33 The Akademi Pimpinan Perusahaan was a semi-academic, secondary-level institute in Jakarta that was intended to develop the capability of young people as candidates for company leadership. In the school year 1961/1962, it had 650 pupils and twenty-four graduates. 


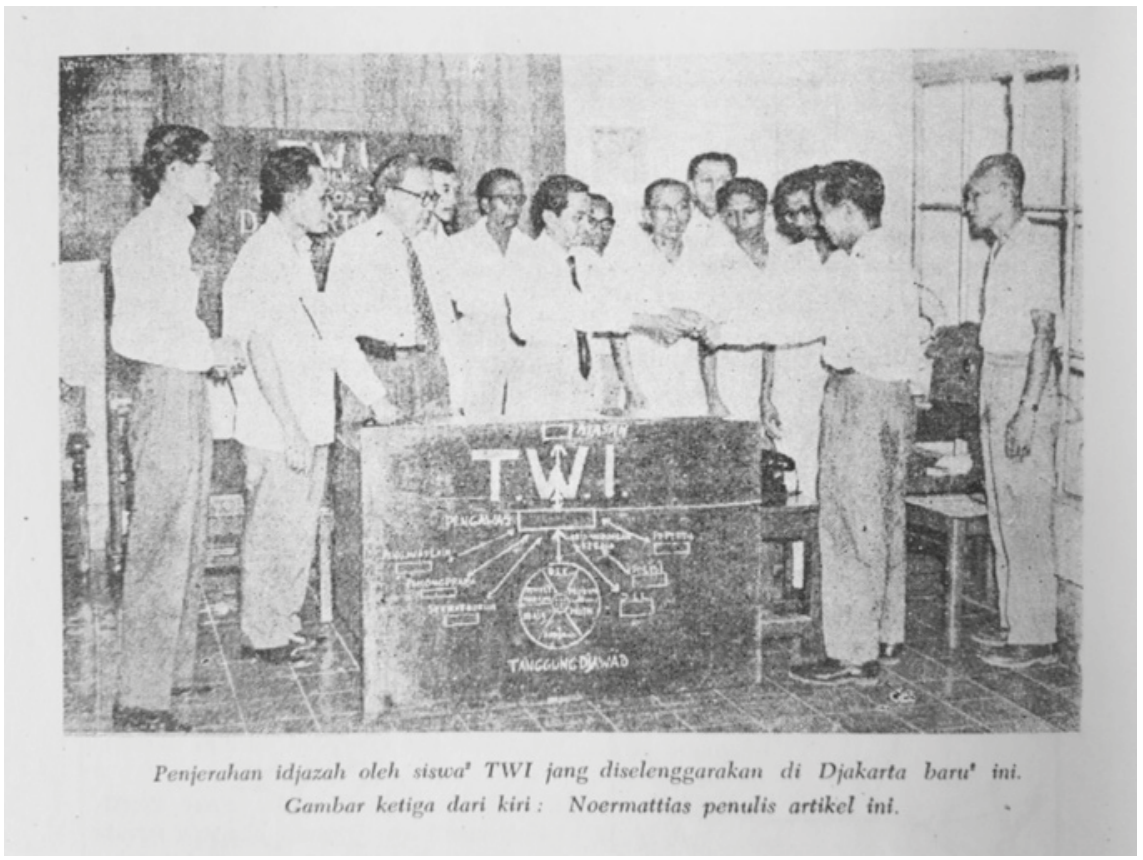

FIGURE 8 The handing over certificate for students for attending the Training Within Industry course in Jakarta SOURCE: MADJALAH INDUSTRI RAKJAT, NO. 3 (II) MARCH 1963, P. 66

trainers. The cost of this course was not covered by the government but had to be paid for by the companies that sent the students. ${ }^{34}$

American corporations dominated these training programmes. The first major actor in this area was the oil company Stanvac, which sent Indonesian employees on courses designed to enable them to take on managerial and supervisory positions. The first scholarships were awarded in 1954, when an accountant was sent to Cornell University and a manager to the Graduate School of Business Administration at Harvard. Employees were also sent to study business administration at the American University in Beirut, Lebanon and Stanford University, California. Legal specialists were sent to Leiden University, the Netherlands, among others. ${ }^{35}$ By 1959, Stanvac had sent fifty-nine employees abroad. The United States also provided direct assistance to Indonesian companies. USAID worked with the College of Business Administration

34 'Program Latihan Pembina/Dosen Azas2 Management', Fortuna, 3/28 (July 1962), 12.

35 Benjamin Higgins, United States Business Performance Abroad. The Case Study of Stanvac in Indonesia (n.p.: National Planning Association, 1957), 76. 
of Syracuse University to provide a twelve-month programme for Indonesians to study the principles of scientific industrial management and to receive specialized training. In total, fifteen Indonesians attended the programme. Its alumni subsequently developed their own management training in Indonesia, working with the Indonesian Chamber of Industries (Kamar Industri Indonesia) to set up a one-month management course in $1959 \cdot{ }^{36}$ It became clear that corporate-sponsored management courses produced better managers than the university system. ${ }^{37}$

The Banas and other government-owned companies with a significant army presence conducted specialized courses for military personnel. In May 1959, the Bappit held its first management course, which catered to professional soldiers who had taken on the role of administrator. In the same month, the Indonesian Chamber of Industries held a management seminar with participants attending from various private industries. In July, the Indonesian Chamber of Commerce (Kamar Dagang Indonesia) held a business management training course, while the Siliwangi Division laid on a six-month-long army middle management training programme, sponsored by the East Java branch of Bappit ${ }^{38}$

The growing relationships between the FEUI, the Finek, government departments such as the Labour Ministry (Kementerian Buruh), the tax office, and the Banas indicate that a community of policymakers and experts was coalescing within these groups which spanned the economic sector, the military, the bureaucracy, and the universities. Management science provided a language that was elitist and professional. It was dominated by an Anglicized and scientific culture that determined a specific and elitist white-collar world view. It was a language that promoted both the magic of efficiency and effectiveness and feelings of communal solidarity and superiority.

The dual rise of military and state managers blurred the lines between the private and public sectors. The private sector had been in decline since the start of the Guided Democracy. The disastrous monetary reforms of August 1959 had effectively attacked both foreign and domestic capital. Many policymakers thought little of Indonesian entrepreneurs, considering them to be speculators and 'black marketeers'. ${ }^{39}$ The expansion in management occurred in the public sector. By the early 196os, Nasution could claim that the military

36 Panglaykim, Report on Business Management Training in Indonesia, 13-14.

37 Panglaykim, Report on Business Management Training in Indonesia, 15 .

38 Panglaykim, Report on Business Management Training in Indonesia, 17-19.

39 Benjamin Higgins, 'Introduction', in Entrepreneurship and Labor Skills in Indonesian Economic Development (New Haven: Southeast Asian Studies, 1961), 35. 
TABLE 12 Management courses provided to state managers

Topics $^{\mathbf{a}}$

General Management

Personal Management

Hubungan Perburuhan (Labour

Relations)

Marketing

Pengenal Barang (Goods

Identification)

Transport Ekonomi (Economics

of Transportation)

Budgetary Control

Finance

Ekonomi (Economics)

Perdagangan Internasional

(International Trade)

Perbankan (Banking)/Public

Finance

Work College Perdagangan

(Trade)

Communications in

Management

Hukum Perdata (Civil Law)

Pelanggaran Ekonomi

(Economic Crimes)

Assuransi (Insurance)

Hukum Fiskal (Fiscal Law)

Hukum Dagang (Trade Law)

Koperasi (Cooperatives)

Research Methodology

Special/Guest Lecturer

Leadership

Cooperatives

\section{Teacher}

Drs. Ang Giok Hoen (University of Indonesia)

Drs. Lo Siang Hien (Department of Labour)

Sutarto (Department of Labour)

Drs. Barli Halim (University of Indonesia)

Pandelaki (Customs Office)

Drs. Suhono (Finek Bureau)

Drs. Sardjono (University of Indonesia)

Drs. Njo Tjians Bik (University of Indonesia)

Dr Mohammad Sadli (University of Indonesia)

Dr Subroto (University of Indonesia)

Drs. Sutarto (University of Indonesia)

Drs. Sutadi (BUD)

Wirasutisna MA (Finek Bureau)

Mr Siregar (Director of API)

Mr Murtolo (Attorney General's Office)

$\mathrm{Mr}$ Siregar (Insurance Cooperating Institute)

Surjono (Tax Office)

Mr Siregar (Director of API)

Ir. Ibnu Sudjono (Cooperatives Office)

Drs. Ismail (University of Indonesia)

Minister of Land Transportation

Minister of Transkopemada (Transportasi,

Koperasi dan Masyarakat Desa)

a Language remains in original form; italics show translations

SOURCE: MADJALLAH PERUSAHAAN NEGARA, 1/1 (1961), 24 
had many people with experience in management and that these people needed to be distributed within the field of development. ${ }^{40}$

\section{$4 \quad$ Public Management: Lembaga Administrasi Negara}

The report of Edward Lichtfeld and Alan C. Rankin, published in 1954, was influential in the development of Indonesian public administration education. One of the main suggestions made was to create a centralized education institute for public administration specialists. While several were developed, such as the UGM's Balai Pelatihan Administrasi and Pajajaran State University's Faculty of Administration, both founded in 1962, and the Interior Ministry's Local Government Training Academy (Akademi Pemerintahan Dalam Negeri, APDN) in Malang, the LAN became the country's primary institution for public administration education. It was developed under the Djuanda Cabinet. Although its creation was suggested by Lichtfeld and Rankin, the LAN prided itself on its 'indigenous' character. The main goals of the institute were to provide training and supervision of the education of civil servants and/or candidate civil servants, to conduct research in the field of public administration, to provide services to improve and perfect government administrative apparatuses, and, lastly, to further develop the science of Indonesian public administration.

A committee was set up in July 1954, consisting of Vice President Hatta; the head of the B PN, Djuanda; the secretary general of the Ministry of Culture and Education, M. Hutasoit; and the secretary general of the Ministry of the Interior, Sumarman. This committee agreed that an Indonesian programme for public administration education should be created under the guidance of Indonesians and that public and business administration science should be grouped within a unified faculty. In 1956, Hutasoit, Sumarman, and Ali Budiardjo conducted a series of meetings and presented their findings to the secretary general. A new preparatory committee was created consisting of the secretaries-general of the Ministries of Education and Culture, Interior, Finance, and Labour, as well as the vice-director of the BPN and the head of the Office of Personnel Affairs (Kantor Urusan Pegawai). This committee reported to then minister of education and culture Sarino Mangoenpranoto and, at the Ministerial Board (Dewan Kementerian) meeting in early 1957, Minister Mangoenpranoto presented the findings. It was finally agreed that a public administration institute needed to be formed. 
In August 1957, Karnandi Wargasasmita, Sumarman, and M. Ulfah Santoso went abroad on a fact-finding mission. At the same time, a delegation from the Institute of Public Administration in Manila, led by Carlos N. Ramos, visited Indonesia. The LAN remained well connected to the wider international public administration networks. At a regional conference on public administration held in Manila in July 1958, Prajudi Atmosudirdjo and Arifin Abdulrachman, both of whom had obtained top positions in the LAN, represented Indonesia, along with Marsoro and Z. A. Samil. The conference created the Eastern Regional Organization for Public Administration, or EROPA. As a follow up by the ICA to the Lichtfeld and Rankin report, Joseph L. Sutton, an adviser to the state administration institute at Thammasat University, Bangkok, was sent to Jakarta. The ICA focused on two things: importing literature on state administration to Indonesia and sending young Indonesians to study the science in the United States. ${ }^{41}$

Prajudi Atmosudirdjo was appointed head of the LAN on 5 May 1958. He had worked as a senior officer in the Department of Industry under the Ministry of Economic Affairs ${ }^{42}$ and had lectured in the Management Faculty of Dwipajana University in Jakarta, writing a book on public management in 1956. In 1959, the LAN set up its first foreign cooperation with Indiana University within the Indonesian Public Administration Project, a five-year programme that allowed seventy-one Indonesian officials to train in the United States. ${ }^{43}$ The US provided funds to the tune of $\$ 586$,ooo for the LAN-Indiana University project. ${ }^{44}$ As well as the US, the LAN also worked with the UN, West Germany, the Colombo Plan, and Japan. In the period 1959-1962, the LAN sent eighty-nine people abroad to study; seventy went to the US, fourteen to the Philippines, three to Japan, and one each to West Germany and Australia. ${ }^{45}$ Staffing remained a problem as experienced managers were hard to pry from their comfortable jobs, and young people were reluctant to join because of the low pay. ${ }^{46}$ As well as Indiana University, the LAN also had links with international organizations such as the International Institute of Administrative Sciences and EROPA. ${ }^{47}$

The LAN-Indiana University cooperation programme was the institute's most important international relationship. Most of its employees who were

\footnotetext{
41 Buchari, Buku Peringatan Pantjawarsa, 46-54.

42 Djojohadikusumo (ed.), The Government's Program on Industries, 1.

43 Sondang Paian Siagian, "The Development and Problems of Indigenous Bureaucratic Leadership in Indonesia', PhD dissertation, Indiana University, Bloomington, 1965, 245.

44 Mahajani, Soviet and American Aid to Indonesia, 13.

45 Buchari, Buku Peringatan Pantjawarsa, 28.

46 Buchari, Buku Peringatan Pantjawarsa, 12.

47 Siagian, 'The Development and Problems of Indigenous Bureaucratic Leadership', 97-8.
} 
sent abroad for higher education were sent to Indiana University, although some went to other US universities. The vast majority of the LAN's books and manuals, audio-visual equipment, printing presses, and other equipment were given by Indiana University with the financial help of the Ford Foundation, or were purchased with the Indiana University courses in mind. In addition to Indiana University professors, the LAN also regularly invited other foreign professors to give talks. They included, in 1960, Harold Koontz, the famous management professor from the University of California, and John Richard Hicks, an economist from Oxford University. Conversely, the LAN also sent people to attend conferences or give talks abroad, including a visit by Arifin Abdurrachman vice principal of LAN, and Prajudi Atmosudirdjo, head of the LAN, to the US, to an IIAS (International Institute for Administrative Science) conference in Lisbon, and to an EROPA conference in Tokyo. ${ }^{48}$

The focus of the LAN inevitably gravitated towards education, based on the following principle: 'When Indonesian leaders, political, community and civil servants, clearly understand what is meant by the subject of public administration, it will be possible to carry out successfully extensive administrativemanagement improvement projects. ${ }^{\prime 49}$ Various short courses were run in cooperation with other state institutions, such as the Depernas and individual departments. The LAN also ran courses for lower-level managers, including a course for the 145 lurah (head of subdistrict) in Jakarta working in cooperation with the municipality. On average, two hundred to five hundred people attended these annual courses. The scope of education was significantly widened when, on 7 November 1960, the University for the State Public Administration Service (Perguruan Tinggi Dinas Ilmu Administrasi Negara) was founded. It had the best library on public administration in Indonesia, ${ }^{50}$ containing the latest American books on the subject. In the same year, the LAN conducted various efficiency surveys in many government departments; produced manuals on management, form design, supervision and reporting; and sent out consultation teams to various institutions such as banks, the army and air force headquarters, the Department of Justice, and prison offices.

The idea of the LAN as the coordinator of civil service administration was an essential component in unifying the fragmented civil service corps. This fragmentation was a result of political party infiltration and this was to be fixed through re-education with proper scientific management courses.

48 Buchari, Buku Peringatan Pantjawarsa, 46-53.

49 Jones, 'Some Critical Areas', 13.

50 Siagian, 'The Development and Problems of Indigenous Bureaucratic Leadership', 97. 
Unfortunately, Prajudi Atmosudirdjo failed to provide the leadership needed to enable the necessary educational restructuring to occur. This failure was very much a result of the director's lack of authority with the ministries involved. ${ }^{51}$ The LAN failed to convince the universities to back the restructuring and there was competition between the organization and the universities to provide public administration courses. Although the LAN attempted to reorganize the subject's curriculum and structure during the 1961 Conference on the Teaching of Public and Business Administration at Universities, Institutions of Higher Education, and Academies, it failed to do so. ${ }^{52}$

\section{Guided Democracy Management}

Both the Lichtfeld and Rankin and the Caldwell and Timms reports approached the institutions of Indonesia's state and education system with an almost naïve lack of political perspective. Naturally, they only met with the most technocratic elements of the Indonesian state: Lichtfeld and Rankin came at the behest of the University of Indonesia, and Caldwell and Timms at the request of the вPN. The Guided Democracy changed all that because of the increasingly political nature of the formerly less-political decision-making institution. The most significant change was the effective reorganization of the Central Bank from being an independent organization to being part of one of the president's ministries. ${ }^{53}$ Another difference between the 1950s and the 196os within administration science was the development of a distinct specialism called development administration. The reason for this evolution was that public and business administration science had been developed for the American political economy and its application to the Third World had required its contextualization. Another reason for its development was the growing awareness that administrators and the science it brought forth would have to operate within an elite system that differed from that of the West and that lacked the presence of a strong state where the rule of law operated.

The roots of development administration germinated in the evolution of a comparative approach during the early 196os. This approach, driven by a cadre of American public administration specialists within a group called the

$5^{1} \quad$ Djuna Hadisumarto, 'The Indonesian Civil Service and its Reform Movement', PhD dissertation, Indiana University, Bloomington, 1974, 182-3.

52 Hadisumarto, 'The Indonesian Civil Service and its Reform Movement', 182-3.

53 Radius Prawiro, Indonesia's Struggle for Economic Development. Pragmatism in Action (Kuala Lumpur: Oxford University Press, 1998), 3. 
Comparative Administration Group, or CAG, was integral to the emergence of development administration. In Asia, the CAG formed the Asia Committee, which allowed many of the pioneers of comparative-administration science to try applying their ideas to real-world problems. Milton Esman of the University of Pittsburgh, for instance, worked in the Development Administration Unit of the Malaysian prime minister's office. Within EROPA, the creation of a Development Administration Group in 1966 signalled the expansion of this relatively tight-knit community of experts. The section was composed of seven members, including Dr Sondang Siagian of the LAN. ${ }^{54}$

As part of the reorganization of the Guided Democracy in the early 196os, to allow for the greater participation of experts in the decision-making process, a series of congresses (musjawarah) was held across all the sciences. These meetings were meant to integrate the sciences with the nation's development plans. On 1 and 2 December 1961, the Department of Higher Education and Science held a congress in cooperation with the BPA, Gadjah Mada University, 55 and the LAN to discuss the influence of higher education on public administration and business management within the universities themselves. The seminar was biased towards public administration, despite the attendance of several business management specialists, such as Barli Halim and Soebroto from the FEUI. ${ }^{56}$

In an article on development administration, written after the fall of the Guided Democracy, Sondang Siagian reiterated the existence of four groups of elites: the power elites or political elite, the task elites or top administrators, the captains of industry, and the intellectuals. Following the arguments adopted by Barli Halim in his papers on the rise of the New Order, Siagian stated that development administration should focus on pioneering changes: 'It is an overall development that is simultaneously integrated into political, cultural, social, and economic development. ${ }^{57}$

54 Sondang Paian Siagian, Administrasi Pembangunan dalam rangka Nation Building (Jakarta: Lembaga Administrasi Negara, 1968), 2-4.

55 The Balai Pembinaan Administrasi ran courses for over two thousand students from various government departments on many topics, including general managerial knowledge, company administration, and efficiency. It also provided consultancy services and carried out research for various firms and government agencies in the Central Java area. Pantja Warsa Balai Pembinaan Administrasi Universitas Gadjah Mada (Yogyakarta: Balai Pembinaan Administrasi-U GM, 1965), 31-7.

56 Laporan Musjawarah Ilmu Administrasi Negara dan Niaga (Jakarta: Lembaga Administrasi Negara, 1962), 65 and 69.

57 Tjokroamidjojo, Administrasi Pembangunan, 2. 'Pioneering dan changes ini menjangkut djuga bidang2 politik, kulturil, sosial, ekonomi dan lain2. Djadi satu pembangunan jang 
The premise of the Guided Democracy as a managerial revolution was voiced throughout the period. In his book, Achmad Sanusi pointed to the need to see Sukarno's Revolusi and the administrative sciences as linked: 'A group of leaders (tokoh) should be created that could push members of society towards a more productive and efficient way of working and one that could avoid [...] speculation and corruption. ${ }^{58}$ Public administration specialists had to develop a model that could be used by the Indonesian government to complete its administrative revolution. Sanusi proposed two approaches. First of all, traditional Indonesian forms of leadership should be studied, such as the gotong royong element of village life and bapakisme $e^{59}$ culture. Improving upon these would develop an effective administrative system using models that were already at hand within Indonesian society. The second approach should be a comparison of Eastern (Russian, Chinese, Yugoslavian, Polish, et cetera), Western (American, English, French, Norwegian, et cetera), and non-aligned (Cuban, Brazilian, Indian, et cetera) administrative systems to find the one most suitable for Indonesian use. ${ }^{60}$

Public and business administration specialists conducted comparative studies that increasingly focused on communist countries as a way to maintain a level of relevance in society. Achmad Sanusi's religious background did not prevent him from exploring communist societies, including writing articles with titles such as "The Administrative System of Russia: A Comparison between the Reign of the Tsar and the Stalin-Khruschev Period', 'An Analysis of the Five-Year Development Plan of Hungary', 'Foreign Trade between Yugoslavia and the US', 'The Yugoslavian Workers Council', and so on. Comparisons with the American managerial system and its focus on business management science contrasted with the Russian focus on engineers and engineering as the basis for managerial science.

At the end of the 196os, Soehardiman, a military manager during the Guided Democracy period, wrote: 'From the time when the community was still in a traditional state to its development as a modern state, the nationaldevelopment administration has had a role as the creator of dynamism, stability, acceleration, and modernity; it is even the key to changing, creating,

merupakan totalitas jang terintegrasi daripada pembangunan dibidang politik, kulturil, social dan ekonomi.'

$5^{8}$ Achmad Sanusi, Masalah Administrative Leadership (Bandung: Universitas Bandung, 1964), 22-3. 'Hendaknja terbentuk satu barisan tokoh2 jang mendorong anggauta2 masjarakat kearah bekerdja lebih produktif dan efisien, dan menghindarkan [...] spekulasi dan korupsi.'

59 Formal relationship within bureaucracy or companies that mimicked traditional, paternalistic father and son relationship.

6o Sanusi, Masalah Administrative Leadership, 25-6. 
and moving towards a modern society that is in line with the development of science and technology.'61 The American modernization ideology had come full circle by the time the New Order had begun. The remaining public discourse had moved away from socialism and its implied participatory actions; instead, the idea of a capable managerial leadership had become the mainstay of the Indonesian discourse of modernity. Soehardiman, along with many others, considered Suharto's success to lie in his brilliant management skills and strategic capabilities. A collection of articles from seventeen Suharto ministers extolling his managerial capability was published in 1996, a year before the financial crisis brought down the Indonesian economy. ${ }^{62}$

\section{Tools and Authorities}

Both Indonesian and American experts recognized the problem of creating a formidable public administration. Joseph M. Waldman was confronted with these problems during the Indiana University project while aiding the LAN in establishing a national training centre for office administration. He quoted several Western experts on the problem of authority: 'I'm sure we've reported to you on several occasions that Mr Mintorogo (deputy director) and others are very reluctant to make those decisions which involve the fact that they have to face up to someone and say "no", or administer correction, or deprive them of what they want to do.' Further, 'on occasions, when some operational or procedural problem had come up and we've asked that he (deputy director) clear this with the LAN and provide us with a pattern for action, he then pleaded that I (chief of party) or Joe should take the matter up with the officials involved, because we were foreigners and that they would listen to us but would pay no attention to him. ${ }^{63}$ A reluctance to cooperate with foreign experts had been noted since the early 1950s: 'Indonesian officials display a touchiness about

61 Soehardiman, Kupersembahkan kepada Pengadilan Sejarah, 238. 'Dari semendjak keadaan masyarakat masih dalam taraf yang tradisional hingga perkembangannya pada taraf modern sekarang ini, administrasi pembangunan nasional mempunyai peranan sebagai dinamisator, stabilisator, akselerator, dan modernisator, bahkan merupakan kunci serta daya penggerak untuk merubah, membangun dan mengembangkan kearah modernisasi masyarakat sesuai dengan kemajuan ilmu pengetahuan dan teknologi.'

62 Riant Nugroho Dwidjowijoto, Manajemen Presiden Suharto (Penuturan 17 Menteri) (Jakarta: Yayasan Bina Generasi Bangsa, 1996).

63 Joseph M. Waldman, 'Administration Problems Encountered in the Establishment of the National Center for Office Administration in Djakarta, Indonesia', PhD dissertation, Indiana University, Bloomington, 1966, 119-20. 
prerogatives, prestige, self-esteem that is a hyper-reaction against the former authority of foreigners, heightened by a frequent sense of insecurity arising from feelings of personal inadequacy for the jobs held. ${ }^{64}$

Many of the publications and conferences on public administration focused on the problems of leadership in, and the decision-making of, the civil service, that is, the problem of authority. There were three general themes in the discussion of public management at the LAN and in other places, such as at APDN or on FEUI management courses. One focused on behavioural capabilities, decision-making, and the devolution of authority. Sondang Siagian proposed changes to create a more active civil service: a better system of recruitment with entrance exams; a better classification of positions; efficiency ratings; better career planning and a greater flow of civil servants from one agency/department to another; better compensation schemes; and, lastly, an improved retirement system. ${ }^{65}$

As in the case cited by Waldman's study, the problem of authority was seen as being much deeper than a question of inadequate remuneration, although this was blamed too, to some extent. Another prominent social science that often figured in such discussions was that of psychology. Books on psychology, offering quick remedies, were available as early as the 195os. Many ideas on leadership rallied around the slogan 'the right man in the right place', which was a somewhat tacit statement about the difficulty of actually drilling and coaching the 'wrong man' into being a good manager, despite advances in the field of psychology. Even so, the notion of coaching a person into excellence in administration was nursed throughout the period.

The second theme related to technical matters of efficiency, especially concerning the office. Many books and articles released by the LAN or the APDN focused on expounding technical developments concerning both work behaviour and office formats. Motion studies - for instance, those developed by the American engineer Frank B. Gilberth and his wife Lillian M. Gilberth in the late nineteenth century - technically dissected the movements of a person working in an office. Seventeen movements were identified and the extent to which they used energy was assessed. These were then linked with time studies, creating time-motion studies. ${ }^{66}$ These and other 'tools', such as the 'critical

64 'Foreign Technical Assistance in Economic Development In a Newly Independent Country', 78 .

65 Siagian, 'The Development and Problems of Indigenous Bureaucratic Leadership', 206-34.

66 A prominent Gadjah Mada social scientist, Drs. The Liang Gie, was quite adamant about promoting these studies. See his article on limiting necessary motion at the office. The Liang Gie, 'Penghematan Gerak dalam Pekerdjaan', Buletin Lembaga Administrasi Negara, 3 (1963), 23 and The, Tjara Bekerdja Efisien. 
path method', which was meant to evaluate and estimate the schedule, costs, and resource allocation for a particular project, ${ }^{67}$ were all being taught to government officials through these managerial courses. Like time-motion studies, Americans dominated this field.

\section{Political Indoctrination and Retooling}

No other 'tool' of management came to be implemented as widely as that of indoctrination, with the exception of the benignly named 'retooling', a shorthand for what amounted to political purges in the offices as shifting influences within Sukarno's inner circle affected those working below them. Similar to many tools of modern scientific management, indoctrination focused on the matter of control; that is, control of the minds of those working under you. Indoctrination had naturally had a history long before the arrival of scientific management, but the indoctrination package that was implemented during the Guided Democracy was couched within the modern and cheerful language of rationality and efficiency. It formed part of Sukarno's dream of creating a New Indonesian Man, which sat at the very heart of the Guided Democracy experiment. In his famous and important Independence Day speech of 1959, Sukarno said:

In order to overcome all the problems associated with our near-term and long-term goals, it is obvious that we cannot use the present systems and tools. We must rid ourselves of liberalism; in exchange, we must replace it with guided democracy and guided economy. The inefficient arrangement of apparatuses must be taken apart. New arrangements (ordening) must be made and re-arrangements (herordening) carried out, so that both guided democracy and guided economy can be achieved. This is what I meant when I spoke of 'retooling for the future'.68

67 Julianto Moeliodihardjo, 'Perentjanaan dan Pengawasan dengan "Critical Path Method", in Tumpal Dorianus Pardede (ed.), Latihan Pembangunan Ketatalaksanaan. Pemikiran Pendahuluan Mengenai Management Berdikari 1965 (Jakarta: Fakultas Ekonomi UI, 1965).

68 'Maka untuk menanggulangi segala mas'alah2 berhubung dengan tudjuan2 djangka pendek dan djangka pandjang tersebut, njatalah kita ta' dapat mempergunakan sistim jang sudah2 dan alat2 (tools) jang sudah2. Sistim liberalisme harus kita buang djauh2, demokrasi terpimpin dan ekonomi terpimpin harus kita tempatkan sebagai gantinja. Susunan peralatan jang ternjata ta' effisien dulu itu, harus kita bongkar, kita ganti dengan susunan peralatan jang baru. Ordening baru dan herordening baru harus kita adakan, agar demokrasi terpimpin dan ekonomi terpimpin dapat berdjalan. Inilah arti dan isi 
As with national planning, scientific management promoted a state-society relationship that elevated the 'experts' within society as natural leaders. These experts occupied positions of importance in several organizations and maintained close contact with each other and, importantly, with members of the military. The rise of military managers, which Utrecht labelled 'military entrepreneurs', ${ }^{69}$ within the nationalized companies resulted in a large number of army personnel managing relatively sophisticated businesses.

Opening the door for indoctrination coaching in high-level government offices, Djuanda proclaimed that

retooling and indoctrination will not only take place in the lower levels of government, but in all state apparatuses from the lowest to the highest, including among the ministers. Retooling and indoctrination are needed in the whole of society in order to create a just and prosperous society. Our retooling and indoctrination efforts will also crack down on private and state-owned companies, which will be reorganized so as to work in a better and more perfect manner. Not all the leaders/directors of these companies do their work perfectly. As a result, there needs to be a reorganization and screening within these companies. ${ }^{70}$

Thus 'retooling' imagined the disciplining of the body politic on an individual level.

Books on military administration, for instance, were derived from general scientific administration publications, discussing the theories of Henry Fayol, James Burnham, the PODSCORB ${ }^{71}$ approach, and many of the latest ideas that had emanated from America. As Herlan phrased it:

Those (administrative) regulations and procedures above, after being practised and perfected through the development of the army's organization and procedures, were then published in book form [...]. The content of the book will be discussed fully in future classes. By 'indoctrinating'

perkataanku mengenai "retooling for the future”.' Sukarno, 'Penemuan Kembali Revolusi Kita', in Tudjuh Bahan2 Pokok Indoktrinasi (Jakarta: Dewan Pertimbangan Agung, 1962).

69 Ernst Utrecht, 'The Military Elite', in Malcolm Caldwell (ed.), Ten Years Military Terror in Indonesia (Nottingham: Spokesman Books, 1975), 41-58.

70 Nanulaita, 'Ir. H. Djuanda Kartawidjaja', 148-9.

71 PODSCORB is an acronym in the field of management and public administration representing a classical approach in organizational theory. 
the officers, the army's 'new-style' administration can be implemented correctly. ${ }^{72}$

The role of the military in this reorganization stemmed from Nasution's anticorruption effort, which had increased military participation in society during the second half of the 1950s. The role of the universities and other government institutions was also significant. ${ }^{73}$ The LAN provided a platform for people to write about the problems of indoctrination, including a piece in its journal in 1961:

Indoctrination is part of the pattern of civilization of large countries like the United States and the Soviet Union; it is only proper and necessary if, in Indonesia, indoctrination is based on the social philosophy of the Pancasila. The problem now lies in its implementation, as most of the indoctrinators themselves have unwittingly become unpaid propagandists for the philosophy of social liberalism as a result of their long exposure to education based on this philosophy. It is fortunate that the basic civilizational pattern of Indonesia is being pioneered by the Universitas Gadjah Mada through its Studium Generale, while the Academy for Interior Governance in Malang has already ensured satisfactory results for the course on Pancasila for the academic year 1959/1960. ${ }^{74}$

72 Herlan, Administrasi Umum dalam Angkatan Darat Kita: Indoktrinasi Administrasi pada Tg. 1 April 1963 (Jakarta: Departemen Angkatan Darat, 1963), 8. 'Ketentuan2 dan prosedur2 diatas, setelah mengalami "praktek" beberapa tahun dan disesuaikan dengan perkembangan2 dalam organisasi dan tata-tjara dalam staf AD kita, kemudian dibukukan dan dikeluarkan oleh DITADJ dalam bentuk [b]uku [...]. Isi dari buku tersebut akan diuraikan lebih mendalam dalam kuliah2 berikutnja. Maka melalui para pedjabat2 jang telah "geindoctrineerd" nanti diharapkan administrasi AD dengan "gajabaru" itu dapat dilaksanakan dengan sebaik-baiknja.'

73 University lecturers were required to go through indoctrination coaching; some five hundred lecturers underwent such coaching between 1962-1965. Bachtiar Rifai, Perkembangan Perguruan Tinggi, 43 .

74 Ruspana, 'Quo Vadis Peradaban Indonesia', Lembaga Administrasi Negara (1961), 42. 'Dengan penelitian adanja indoktrinasi sebagai realisasi dasar pola peradaban di negeri2 besar Amerika Serikat dan Soviet Uni, wadjar dan keharusan serta wadjiblah kalau di Indonesia didjalankan indoktrinasi sebagai realisasi dasar pola peradaban filsafat social Pantja Sila. Akan tetapi sekarang kesulitannja jaitu dalam bidang pelaksanaan dimana sebagian besar pelaksana2 sendiri dengan setjara tidak disadari mereka mendjadi propagandis tanpa bajaran dari filsafat sosial liberalisme, karena memang sudah sekian tahun mendapat pendidikan berdasarkan bersumberkan filsafat tersebut diatas. Sjukurlah dasar2 pola peradaban Indonesia ini sudah dirintis oleh Universitas Gadjah Mada dengan diadakannja Studium Generale, sedang di Akademi Pemerintahan Dalam Negeri di 
Retooling also facilitated the spread of the military into the various nooks and crannies of society. As Nasution phrased it: 'There is no field where the Karya military force isn't participating. This shows that the APRI (Indonesian Army) has succeeded in conducting retooling. ${ }^{.75}$ A series of professional oaths was created: Panca Setia for the civil service, Sapta Marga for the military, Tri Brata for the police, Panca Wardana for the youth, and so forth, signalling the loss of individual responsibility and its replacement with responsibility to the state.

The State Apparatus Supervision Agency (Badan Pengawas Kegiatan Aparatur Negara, Bapekan), created on 17 August 1959, was the brainchild of General Nasution. ${ }^{76}$ It was a small and centralized organization with forty staff members. It studied the problems of decentralization and the stalemates in the court system. It sent members to observe the arrangements of the Asian Games in 1962, the petroleum industry in Sumatra, and the Rice Centre (Sentra Beras) in Java. ${ }^{77}$ Its duty was to conduct surveillance and research into the working of state apparatuses. ${ }^{78}$ The organization carried out two basic forms of work: passive/routine-type work and active work. Active work consisted of investigations carried out on presidential orders or that were initiated by the Bapekan itself. It also investigated complaints sent from the regions. ${ }^{79}$ One of the Bapekan's weaknesses was that it functioned merely to investigate and recommend solutions, and lacked enforcement capability. 80

The head of the Bapekan was Sultan Hamengkubuwono Ix, the former minister of defence. Widely regarded as an upstanding figure, the sultan was an important symbol of idealism, an outlook that the body wanted to convey to the

Malang filsafat Pantja Sila telah dimasukkan didalam Curriculum tahun pengadjaran 1959/6o dan ternjata hasilnja memuaskan.'

75 Nasution, Memenuhi Panggilan Tugas, Jilid v, 208.

76 Nasution, Memenuhi Panggilan Tugas, Jilid v, 256.

77 Notulen Rapat Bapekan, ANRI, Menteri Negara Ekonomi, Keuangan dan Industri (Menneg Ekuin), inv. no. 39 o.

78 Nasution claimed that initially Sukarno wanted to give the Bapekan to politicians, but he relented so as to maintain the technical nature of the organization, instead of allowing it to become highly politicized. Nasution, Memenuhi Panggilan Tugas, Jilid v, 256 .

79 ANRI, Bapekan, inv. no. 6.

8o Peraturan-peraturan Presiden Republik Indonesia No. 1 Tahun 1959 tentang Pembentukan Badan Pengawas Kegiatan Aparatur Negara (Jakarta: Pertjetakan Negara, 1959), 1-10. 
sceptical Indonesian public. His secretary, sociologist Selo Soemardjan, joined him. ${ }^{81}$ Other members of the Bapekan included Semaun, ${ }^{82}$ an old communist who was famous for being banned by the Dutch East Indies; Samadikoen, a former governor of East Java (1949-1958); and Colonel Soedirgo, a military man. Sukarno pushed for the inclusion of Semaun in order to realize his Nasakom ideals. ${ }^{83}$ Nasution thought that while the composition of the Bapekan was politically strong, it was technically weak. ${ }^{84}$ However, the selection of its members was certainly not based solely on political considerations. Each of them had experience with administration, although none was trained specifically in the American science of public administration. Between January 1959 and July 1959, the Bapekan received 902 cases for investigation, of which 402 were reportedly 'solved', while the rest remained 'in progress'. The Bapekan's recommendations were non-binding.

The National State Apparatus Retooling Committee (Panitia Retooling Aparatur Nasional, Paran) became the other half of the control mechanism of the civil service. If the Bapekan functioned as a research and surveillance

81 Soemardjan, Social Changes in Jogjakarta.

82 Semaun was a communist of long standing who was banished by the Netherlands Indies government in 1923 for his role in the Union of Railway and Tramway Personnel (vSTP) strikes. Initially, he lived in the Netherlands and was active in the Anti-Imperialist League and the Indonesian Association (Perhimpunan Indonesia), rubbing shoulders with Mohammad Hatta and many other Indonesian nationalists before leaving for the Soviet Union in the 1930s. He reputedly studied at Tashkent University, Uzbekistan, before moving to the Institute of Far East Studies in Moscow in 1931, where he studied Soviet rationalization in action at the Rail Office of Baku in the Caucasus, in today's Azerbaijan. He was also reputed to have worked for the planning board of the Soviet Republic of Tajikistan. It was partially based on this experience that he was given a Doctor Honoris Causa by Prof Dr Prajudi Atmosudirdjo, who, aside from being the head of the LAN, was also the dean of Padjadjaran University. He arrived back in Indonesia in December 1956 with much fanfare and to open arms from the nationalist and communist elites of the country, including President Sukarno himself. Meanwhile, by his return to Indonesia he had effectively renounced communism, whose Stalinist excesses he had personally witnessed during his stay in the Soviet Union. Upatjara pemberian gelar Doctor Honoris Causa dalam Ilmu Ekonomi kepada Sdr. Semaun pada hari senin tanggal 31 Djuli tahun 1961, djam 20.00 bertempat di Aula Universitas Padjadjaran djalan Dipati Ukur no. 37, Bandung, ANRI, Bapekan, inv. no. 5 .

83 Nasution, Memenuhi Panggilan Tugas, Jilid v, 257; Harian Rakjat, 16 August 1959.

84 Nasution, Memenuhi Panggilan Tugas, Jilid v, 257. 
body, the Paran had the duty of fixing the problems it highlighted through retooling. ${ }^{85}$ Nasution was the head of the Paran and Roeslan Abdulgani his deputy. The Paran was the brainchild of Nasution, Muhammad Yamin, and Abdulgani. As a result, it incorporated the diverse ideas that the three men had about retooling. The presence of Abdulgani as Sukarno's ideological right-hand man strengthened the president's idea of the Paran as an indoctrination organ for the wider civil service. As Nasution said, 'the president will deal with the mental-ideological retooling, but what I am dealing with is related to organizational order, work order, and personnel problems.' ${ }^{86}$ Nasution thus dealt with the more mundane but important problems of mismanagement.

The first act of the Paran was to continue to carry out the military's anticorruption policy when, in December 1960, all government ministers were required to hand over information about their personal assets. Forms were sent to people in key positions of the civil service in order to determine their loyalty to the state, especially whether they had sympathies with the various rebellions ${ }^{87}$ or had been loyal to the Dutch. This process was extended to cover all civil servants at the F/IV level or above by March 1961. Nasution was concurrently the minister of national security. Meetings were held at the army headquarters. The Paran created the new Pantja Satia oath of civil service loyalty, legalized through Presidential Regulation No. 3/1961, which provided the guidelines for retooling. A law was then proposed on the basic principles of government employment (pokok kepegawaian).

Nasution reiterated the temporal and ad hoc nature of the Paran, saying that it was part of the government's short-term programme, in line with the other Tri Programmes ${ }^{88}$ of the cabinet. He envisaged the Paran as being transformed into a more permanent body, the Body to Manage the Efficiency of the State Apparatus (Badan Pembina Effisiensi Apparatur Negara).

85 Retooling was supported by management specialists when it conformed to the dictates of scientific management. Public officials were especially needed because of their function as corporate managers. Leon Mears, 'Some Management Problems in Indonesia', in Rossal J. Johnson, Mohammad Sadli and Subroto (eds), Teachings in Business Administration and Economics (Jakarta: Lembaga Penyelidikan Ekonomi dan Masyarakat, 1961), 28-30.

86 Nasution, Memenuhi Panggilan Tugas, Jilid v, 256. 'Presiden menggarap retuling mentalideologis, tapi yang saya garap ialah terutama ketertiban organisasi, tatakerja dan personal.'

87 The DI/TII, the PRRI, Permesta, the Madiun Affair, et cetera, comprising representatives of various ideological positions in Indonesia, including Islamist, social democratic, communist, and so forth.

88 The Tri Programmes were: provision of foodstuffs, supporting a secure environment, and continuing the fight against imperialism and colonialism. 
There were three sub-committees under the Paran: the 'mental', personnel, and organizational sub-committees. The 'mental' sub-committee designed a uniform and intensified the indoctrination campaign at the central and regional levels, working under the supervision of the Committee for the Management of the Revolutionary Soul (Panitya Pembinaan Djiwa Revolusi), led by Roeslan Abdulgani. In 1961, the committee published the Seven Major Indoctrination Doctrines to standardize the process, as instructed by Sukarno on 27 February 1960, to intensify indoctrination and quicken the retooling efforts. ${ }^{89}$ The doctrines covered documents on the birth of the national ideology, Pancasila; the Constitution of 1945; the Political Manifesto (Manipol), which embodied the principles of Guided Democracy; Sukarno's main speeches - the Road to Our Revolution (Djalannja Revolusi Kita or Djarek) and Creating the World Anew (Membangun Dunia Kembali); the president's article explaining both Manipol and USDEK ${ }^{90}$; and, lastly, the president's address on the Eight Year Overall Development Plan (Rentjana Pembangunan Semesta Delapan Tahun). ${ }^{91}$ Contained within these documents was a dizzying array of ideas representing Guided Democracy. The committee conducted its first coaching session in May 1961 over a period of five to seven days. There were general coaching sessions for both first- (provincial) and second- (regency) level regional governments.

The organizational sub-committee sent queries to and collected ideas from departments, conducted on-the-spot surveys, sought expert advice on designing blueprints for organizational/procedural work, and, lastly, gave technical retooling advice to the departments in question. This sub-committee was led by Nasution. ${ }^{92}$ It also worked with the Ministry of Internal Affairs and Regional Autonomy (Kementerian Dalam Negeri dan Otonomi Daerah) to design a vertical organization of government. On an ideological level, this sub-committee had the daunting task of fulfilling Sukarno's commitment to leave behind the Western trias politica (the separation of the executive, legislative, and judiciary) in favour of his brand of corporatist unity under the Karya groups.

The idea of retooling was central to the Paran, but it was also highly central to the ideology of Guided Democracy itself. 'Retooling means the dismantling

89 Seno Soesanto, Manipol Usdek. Bahan Batjaan bagi Para Peserta Latihan-latihan Djabatan/ Kursus-kursus pada Lembaga Administrasi Negara (Jakarta: Lembaga Administrasi Negara, 1962), 2.

9o The main guideposts of the Indonesian revolution, USDEK (Undang-undang Dasar 1945, Sosialisme Indonesia, Demokrasi Terpimpin, Ekonomi Terpimipin, and Karakter Indonesia) is an acronym for the following: the Constitution of 1945, Indonesian Socialism, Guided Democracy, Guided Economy, and the Indonesian Character.

91 Sukarno, Tudjuh Bahan Pokok Indoktrinasi (Jakarta: Pertjetakan Negara, 1961).

92 Nasution, Memenuhi Panggilan Tugas, Jilid v, 259. 
of the inefficient arrangement of the apparatus and its replacement with a new arrangement. This is planning and rearranging with the long-term goal of achieving our revolution. ${ }^{93}$ Etymologically, the term was used in scientific management for the reorganization of the factory floor, that is, industrial reorganization. Within society, it meant the mobilization of material and spiritual forces and society's recreation as a strijdvaardig and strijdwaardig (combat ready) force. Within the government it meant reordering in both the legislative, executive, and other fields of government. Its official definition was 'the effort to renovate in the soul, arrangement, work procedures, and personnel of all State organizations in the legislative, executive and other fields at the Centre and the Regions so as to conform to the Political Manifesto and USDEK and to efficiently reach the goals of the State in the short and long term. ${ }^{94}$ The civil service was to be shaped into an efficient bureaucracy through the application of modern management, political education, and purges. A civil servant had to be pro-Manipol and USDEK.

Instead of professionalizing it, the politicization of the civil service damaged it even further. The screening of potentially non-loyal civil servants became a major drive to oust people without the backing of political groups. Instead of looking at people based on their merits, their political stance and personal history became liabilities. For instance, the loyalty issue was highly damaging for those who had historically sided or worked with the Dutch during the revolutionary period. This was the problem for the head of customs in the port of Tanjong Priok, whose professionalism and capability came second to his past political loyalty. Because Indonesia still had a large number of 'collaborators', that is, former officials of the colonial regime, working for the government at that time, such a policy had disastrous consequences for the efficacy of the civil service. ${ }^{95}$

There were two general criteria for determining the acceptability of civil servants: positive and negative norms. The positive norms looked at universal criteria, such as technical capabilities, general capabilities, morality, character, and loyalty. The negative norms looked at the political acceptability of the civil servant within the revolutionary period. This necessitated an inquiry into the personal histories of civil servants. It was important that people were not

93 'Retooling adalah pembongkaran susunan peralatan jang tidak efisien dengan penggantian susunan peralatan jang baru. Ini adalah "ordening" baru dan herordening baru, dengan maksud agar tudjuan djangka pandjang dari revolusi kita dapat tertjapai.' Laporan Panitia Retooling Aparatur Negara, S.1396/9/6o, A. H. Nasution, ANRI, Bapekan, inv. no. 5.

94 Laporan Panitia Retooling Aparatur Negara, ANRI, Bapekan, inv. no. 345.

95 ANRI, Bapekan, inv. no. 81. 
tainted by historical involvement that could bring into question their loyalty to the Republican government, and this included support of the various postindependence rebellions against the central government or having worked as a Dutch collaborator during the revolutionary war. Three absolute characteristics had to be present: pro-Manipol and USDEK; revolutionary rather than counter-revolutionary, using criteria based on Sukarno's 196o Independence Day speech; and, lastly, able to combine all revolutionary forces within the spirit of mutual cooperation (gotong rojong). Civil servants who were weeded out were put into four possible negative categories: anti-Manipol USDEK, who silently opposed Indonesian socialism; anti-Manipol USDE K, who openly opposed Indonesian socialism; those who, because of lack of knowledge, opposed Indonesian socialism; and, lastly, those who lacked knowledge of Manipol but did not oppose it. This political labelling and classification of people was, to say the least, damaging to the formation of an esprit de corps within the bureaucracy.

Instead of announcing Manipol as some sort of international social science experiment, the Indonesian government stressed the ancient and traditional nature of the values behind the teachings that Sukarno had bestowed upon the nation. Thus, the concept of sosialisme à la Indonesia was not to be found in capitalist and liberal Europe, but was 'in fact [...] very old in Indonesia [...] for again it is social justice which is meant here, not merely the implementation of laws, regulations and other social codes. ${ }^{.96}$ Guided Democracy was in fact 'only a new statement of something very old in Indonesia. Since ancient times, democracy in Indonesia has been what we now call Guided Democracy. Since ancient times, Indonesian society has been averse both to dictatorship and to the individualism of liberalism. The old system of government was based upon musjawarah and mufakat with the leadership of a single central authority in the hands of a "sesepuh" or elder, who did not dictate, but led and protected. ${ }^{97}$

Although the regime claimed indigenous roots for its ideology, one could, with little hesitation, support the idea that retooling, indoctrination, and the elimination of counter-revolutionaries within the government was in line with the demands of management science. The structural and 'mental' subcommittees basically rehashed the rhetoric of the more 'scientific' managerial and economic experts, focusing on 'working procedures' and 'organizational efficiency'.

96 Manipol-Usdek in Questions and Answers (Jakarta: Department of Information, 1961), 36.

97 Manipol-Usdek in Questions and Answers, 40. 
Nasution's ambitious goals for the Paran were ineffective. As he himself phrased it: 'Even the effort to regulate the structure of departments was unsuccessful. The ministers maintained their own personal power and obtained their authority directly from the President. I also tried to introduce regional Paran. Governors close to me immediately formed them, but governors close to others at the centre hesitated to do so.98 The result of these exercises was the decidedly military garb that the civil service took on, complete with militarystyle ceremonies, trainings, and indoctrination campaigns.

\section{The Inherent Tension of Guided Democracy Control}

For most observers, the indoctrination efforts of the Guided Democracy were a farce. Retooling meant purging the civil service of unwanted persons. People queued to go on indoctrination courses because they feared that there would be trouble if they did not take the courses. Most of the teaching materials were dull and uninteresting, a list of readings on the state's ideology. This in turn became the standard fare that the New Order state imposed on the rest of society. In 1966, a series of indoctrination classes to purge communists began. Again, the materials presented were less important than the reinforcement of the idea of state control over one's body and behaviour.

By early 1964, Sukarno had successfully wrested control of the Paran from Nasution by creating another body to replace it: the Highest Command for the Retooling of Revolutionary Tools (Komando Tertinggi Retooling Alat Revolusi, or Kotrar). ${ }^{99}$ He viewed the Paran as a threat to his capability to bestow lucrative sinecures as a means to support his authority. ${ }^{100}$ Many military officers also saw it as a threat to their position in the economy. ${ }^{101}$ The Kotrar was headed by Soebandrio, with General Ahmad Yani as chief of staff and Air Commodore Wiriadinata as vice chief of staff. This represented the end of Nasution's

98 Nasution, Memenuhi Panggilan Tugas, Jilid v, 259. 'Untuk penyamaan struktur departemen-departemen saja pun kami tak berhasil. Para menteri telah berkuasa sendirisendiri dan langsung meminta pengesahan dari Presiden. Saya usahakan pula adanya Paran di propinsi-propinsi. Gubernur-gubernur yang dekat kepada saya segera membentuknya, tapi gubernur-gubernur yang agak berkiblat kepada tokoh-tokoh lain di pusat, enggan melaksanakannya.'

99 The communists were represented within Kotrar, much to the dismay of the military. David Mozinga, Chinese Policy toward Indonesia, 1949-1967 (Singapore: Equinox, 2007), 222.

100 Penders and Sundhaussen, Abdul Haris Nasution, 170.

101 Crouch, The Army and Politics, 40. 
effort to implement the managerial sciences within the state structure. As was the case with national planning, Sukarno's politics obstructed efforts to try and implement any sort of rational approach to disciplining state apparatuses.

The ideas of social control, social support, and social participation were central to Sukarno's idea of incorporation. This was apparent in the national planning carried out by the Depernas, and it was also apparent in the Muppenas structure that accompanied the rise of the Bappenas. Social control was meant to 'democratize the political and economic centres of society'. Within government-owned companies, the rise of the Company Board, for instance, was an expression of the intention to create an economy based on an openmanagement system, one in which the managerial policies of the company would be in the hands of the workers as well as the management. There was thus a strong focus on participation within the idea of Guided Democracy. Social control would lead to a successful state precisely because of the support of people within society. In connection with the problems of corruption and what Benedict Anderson has termed the movement of 'society into the state, ${ }^{102}$ the answer was participation as a mechanism to strengthen the legitimacy of the revolutionary leadership. The similarity of social ideals and social goals between the managers and the workers, between the experts and the people, would enable the total support of the people. This was the ideal of the Guided Democracy state.

Social-science analysis has highlighted a dichotomy in understanding the problematized Indonesian Man and the gotong rojong culture. To begin with, there were inherent problems concerning decision-making and leadership capabilities. The traditional cultural values of Indonesia were considered to be the foundation of the modern Indonesian people, leaders, bureaucrats, and managers. These cultural values were strongest amongst traditional-thinking people. The New Indonesian Man had to be both traditional and modern at the same time. His values had to transcend the traditional value system but be rooted in it nevertheless. The efforts made to discipline Indonesians through indoctrination and retooling were modern and rational attempts to create efficiency while simultaneously upholding the traditional values that legitimized them as both leaders and revolutionaries.

102 As was outlined in Anderson, 'Old State, New Society', 477-96. 
At the same time, there was a genuine effort to improve the managerial capability of the bureaucracy through the Bapekan and the Paran. Both bodies tried to implement measures to increase efficiency, which included dealing with problems of a political nature. Like the intentions behind national planning, the early Guided Democracy state was earnest in its attempts to try to make positive changes. Its failure represented the inability of experts to understand the effects of the logical actions of scientific management. Perhaps the most significant legacy of the Guided Democracy movement was its controlling devices and mechanisms, which would continue to be used during the New Order regime. 